\title{
Chapter 3. Remembering Origins: Ancestors And Places In The Gumai Society Of South Sumatra ${ }^{1}$
}

\section{Minako Sakai}

\section{Introduction}

The notion of "origin" is a key concept for comparative studies of the Austronesians. ${ }^{2}$ Two ways of tracing origins have been observed among the Austronesians. One is represented by a genealogy or succession of personal names, demonstrated by various societies in eastern Indonesia. The other is what Fox (this volume) calls "topogeny", which consists of a succession of place names related to the journeys of their ancestors. ${ }^{3}$

This paper aims to illustrate a notable variation on Austronesian origin concerns through an analysis of Gumai ideas about origins. These people trace their origins through a succession of ancestral names. This succession is linked to recognized places of origin. A hierarchy of Gumai origin points, which are identified according to the timing of their generation, is crucial for Gumai ritual practice. Gumai origin rituals, whose core consists of invocations of ancestral spirits, need to be performed by the authentic descendants who act as the Jurai Kebali'an and Jurai Tue (ritual specialists), at origin places represented by origin houses. It is this linkage between persons and places that constitutes the authenticity of Gumai origin rituals and ritual specialists.

In this paper, I will first outline Gumai society where my research was conducted. ${ }^{4}$ Secondly, I will present a brief account of Gumai origin narratives in order to explain the generation of origin points and the origin ritual places, which correspond to each origin point and validate the authority of Gumai ritual specialists. Thirdly, I will explicate various levels of Gumai origin rituals in order to highlight the significance of the association between ancestral spirits and places in Gumai ideas about origins. 

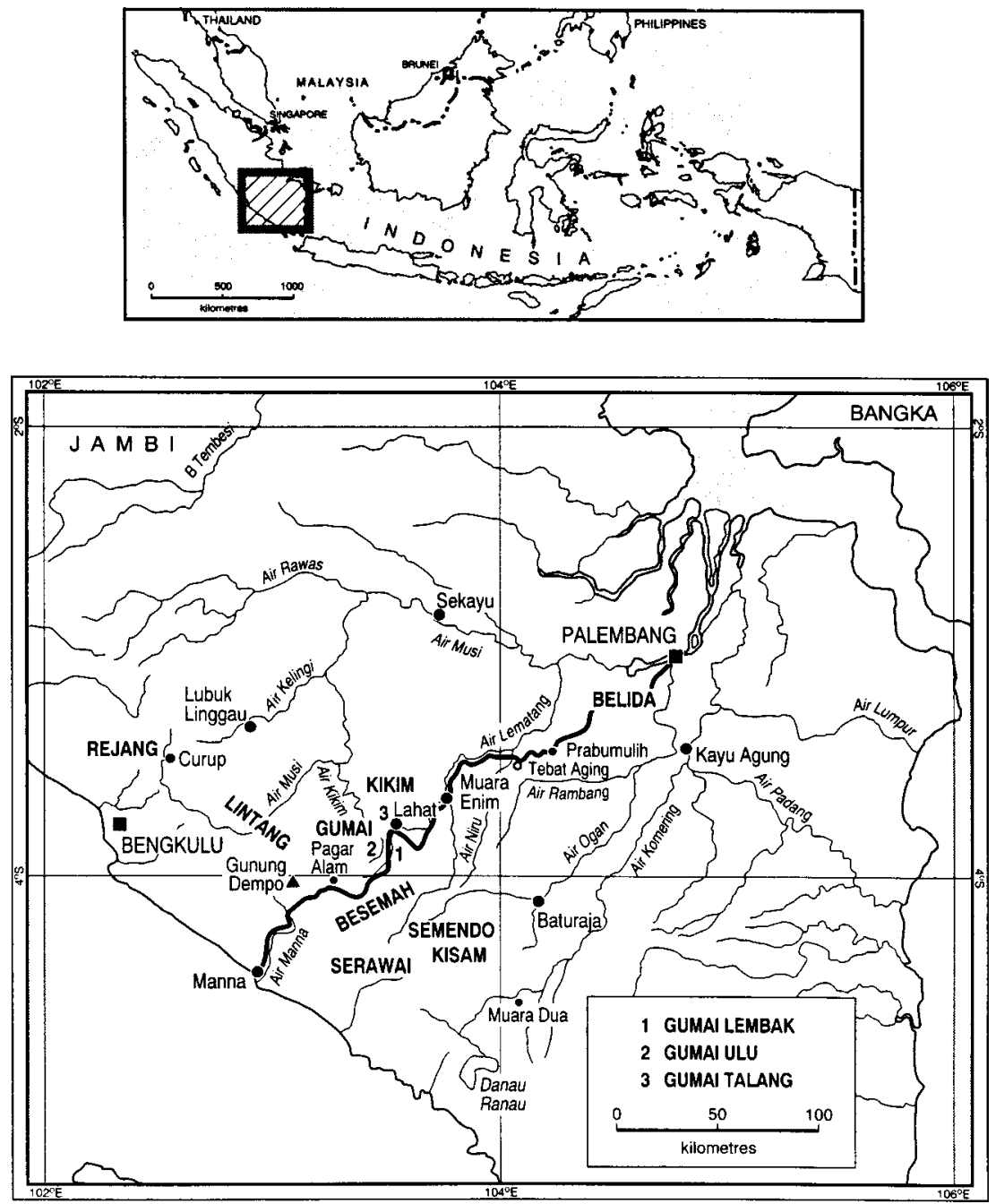

Map 1. Ethnic groups of South Sumatra

\section{The Ethnographic Setting}

The Gumai form one of the ethnic groups in the highlands of South Sumatra Province (Map 1). Their language belongs to one of the Malay dialects widely spoken in Southern Sumatran upstream societies. ${ }^{5}$ Their main villages are along rivers in Lahat and in Muara Enim districts (kabupaten). The data presented here came mostly from Gumai Talang, one of the three main Gumai settlements in Lahat district. ${ }^{6}$

The population of Gumai Talang in 1994 was estimated as 8,281. The settlement consists of fourteen villages, the majority of them situated along the Trans-Sumatran Highway, along which big trucks and buses travel between 
North Sumatra and Java every day. ${ }^{7}$ Villages in Gumai Talang still maintain homogeneity in terms of their custom, tradition and religious practices. A few non-Gumai married to Gumai and living in their villages also observe Gumai customs such as marriage-related ceremonies and village ceremonies.

Table 1. Population in the settlement of Gumai Talang

\begin{tabular}{lcccc}
\hline Village name & Males & Females & Total & Households \\
\hline Tanjung Dalam & 199 & 253 & 452 & 84 \\
Suka Rame & 250 & 326 & 576 & 85 \\
Ngalam Baru & 400 & 450 & 850 & 95 \\
Mandi Angin & 364 & 372 & 736 & 147 \\
Tanjung Baru & 284 & 332 & 616 & 126 \\
Endikat llir & 226 & 312 & 538 & 116 \\
Darmo & 315 & 344 & 659 & 146 \\
Muara Tandi & 250 & 325 & 575 & 134 \\
Tanjung Karangan & 193 & 207 & 400 & 95 \\
Tanjung Periuk & 198 & 357 & 555 & 73 \\
Sugihwaras & 405 & 385 & 790 & 186 \\
Tanah Pilih & 375 & 415 & 790 & 120 \\
Batay & 220 & 195 & 415 & 98 \\
Tanjung Beringin & 172 & 157 & 329 & 76 \\
\hline
\end{tabular}

Source: Fieldwork.

Prior to Dutch colonization, the highlands of South Sumatra were linked to the port polities in the lowlands (Palembang) through the pepper trade. ${ }^{8}$ Yet upland societies, including that of Gumai, remained relatively independent from the rule of downstream societies, represented by the Sultanate of Palembang. ${ }^{9}$ However, when the Sultanate of Palembang fell under Dutch colonial rule in the early nineteenth century, the Dutch proceeded to conquer the highlands. The Gumai fought a war with them between 1856 and 1867, and finally compromised with them (Rustam-Effendi 1993:43-52).

During colonial times, the Gumai near Lahat were divided into three main residential groups which were designated as marga - Gumai Lembak, Gumai Ulu and Gumai Talang - and a pasirah was appointed as the head of each marga. ${ }^{10}$ This marga system remained in force until the Indonesian government implemented new administrative regulations in 1979. ${ }^{11}$ By the mid-1980s, the pasirah or marga system had been replaced by an autonomous village administration. Today each village is headed by a village headman (kepala desa), who is chosen every eight years and is under a camat (subdistrict head).

According to Gumai narratives, Islam penetrated South Sumatran upstream societies at the beginning of this century. Nowadays all the Gumai are formally Muslim and life-cycle rituals such as death, marriage and circumcision are performed according to Islamic rules. Nevertheless, Gumai perform ancestral rituals which still strongly regulate their social life. 
The Gumai consider that the world is divided into several spheres: the sky (aras), mountain/forest (gunung/utan), sea (laut) and earth (bumi); each of these is believed to be controlled by invisible supernatural spirits. Invisible supernaturals in each realm form a group headed by petunggu or junjungan and they are collectively called the four guardians (Empat Diwe). Junjungan di Aras are believed to possess control over life (nyawe), Junjungan di Gunung over security (penangai umat) and well-being, Junjungan di Laut over fortune (rezeki) and finally Junjungan di Bumi, represented by the Jurai Kebali'an, for communication between ancestors and their descendants.

Agriculture provides the main sources of livelihood for the Gumai. They produce coffee, rubber, fruits, coconut oil and dry rice using slash and burn cultivation. They utilize the forests for gathering useful tropical plants such as rattan and medicinal herbs and for clearing plots of land. They fear entering forests because the land in the forest is believed to be controlled by invisible spirits. $^{12}$

Failure to acknowledge the spirits' control over the land is considered to cause misfortune, such as accidents and sickness. Offended spirits will penalize those who have entered and destroyed their domiciles. ${ }^{13}$ To avoid offending the spirits, the process of clearing a portion of land to make a garden is accompanied by a series of rituals, whose purpose is to transfer the control of the land from the spirits to human beings. ${ }^{14}$ These rituals are intended to ask permission of the land spirits for the human beings to use a plot for their needs as tenants (numpang hidup). The interaction among spirits, ancestral spirits and human beings underpins everyday life in Gumai society.

In the following sections, I will outline the generation of various Gumai origin points and will illustrate Gumai concerns with "origin".

\section{The Generation of Origin Points}

Like the majority of groups in Indonesia, the Gumai concern with origin centres around ancestral spirits (arwah puyang). ${ }^{15}$ What is significant to the Gumai is, however, that their ancestral spirits are divided into several categories which constitute generation points. These are, from the beginning, Diwe (The Founding Ancestor), Ratu (below Diwe and before Puyang Ketunggalan), Puyang Ketunggalan (The Single Ancestor), Puyang Ketunggalan Dusun (The Single Village Ancestor) and Puyang Keluarge (Family Ancestors). The older the ancestral spirits are, the more influential they are considered to be. The features of these categories of ancestral spirits derive from the deeds and timing of each Gumai ancestor. To illustrate this, I will start with a brief account of these ancestors as recounted in Gumai oral narratives, many of which have features similar to the origin myth recounted in the Sejarah Melayu. ${ }^{16}$ 
The founding ancestor of the Gumai, Diwe Gumai (see Figure 1, no. 1), is believed to have descended to Earth from Negeri Aras, the country above the sky. He was watching the whole process of creation of the world and was reluctant to go down because the world looked dark. It was after he received the seventh order to descend that he finally jumped to Earth in a fruit one night before the full moon. ${ }^{17}$ He arrived at Bukit Seguntang, which was the only place in the world above the water at that time. ${ }^{18}$ Unfortunately, Diwe Gumai $(1)^{19}$ was trapped within the fruit and could not get out of it. He had to get assistance from Diwe Semidang (A), who descended to Earth the night after Diwe Gumai. Both of them used a spell to open the fruit and eventually Diwe Gumai came out. $^{20}$ After this event, Diwe Semidang went to Pelang Kenidai, at the foot of Mt Dempo, near Pagaralam in South Sumatra Province and settled there. ${ }^{21}$ Due to his position as the apical founding ancestor of the Gumai, Diwe Gumai is referred to as Diwe, which differentiates him from other Gumai ancestral spirits. His position constitutes the ultimate origin point for the Gumai.

Diwe Gumai married a princess from Bangka Hulu (Bengkulu) and was blessed with two sons, Ratu Iskandar Alam (3) and Ratu Selebar Alam (4). Ratu Selebar Alam is believed to have left Bukit Seguntang and to have gone to Pagarruyung in West Sumatra. ${ }^{22}$ He had two daughters. One of them, Putri Kumbang Mibar (7) married Junjungan di Gunung whose name was Ngawa Ratu Diwe Nyawe or Tuan Raje Nyawe. The other daughter, Putri Kumbang Nadar (9) married Junjungan di Aras called Tuan Meraje Sakti or Mentare Sakti. ${ }^{23}$ 


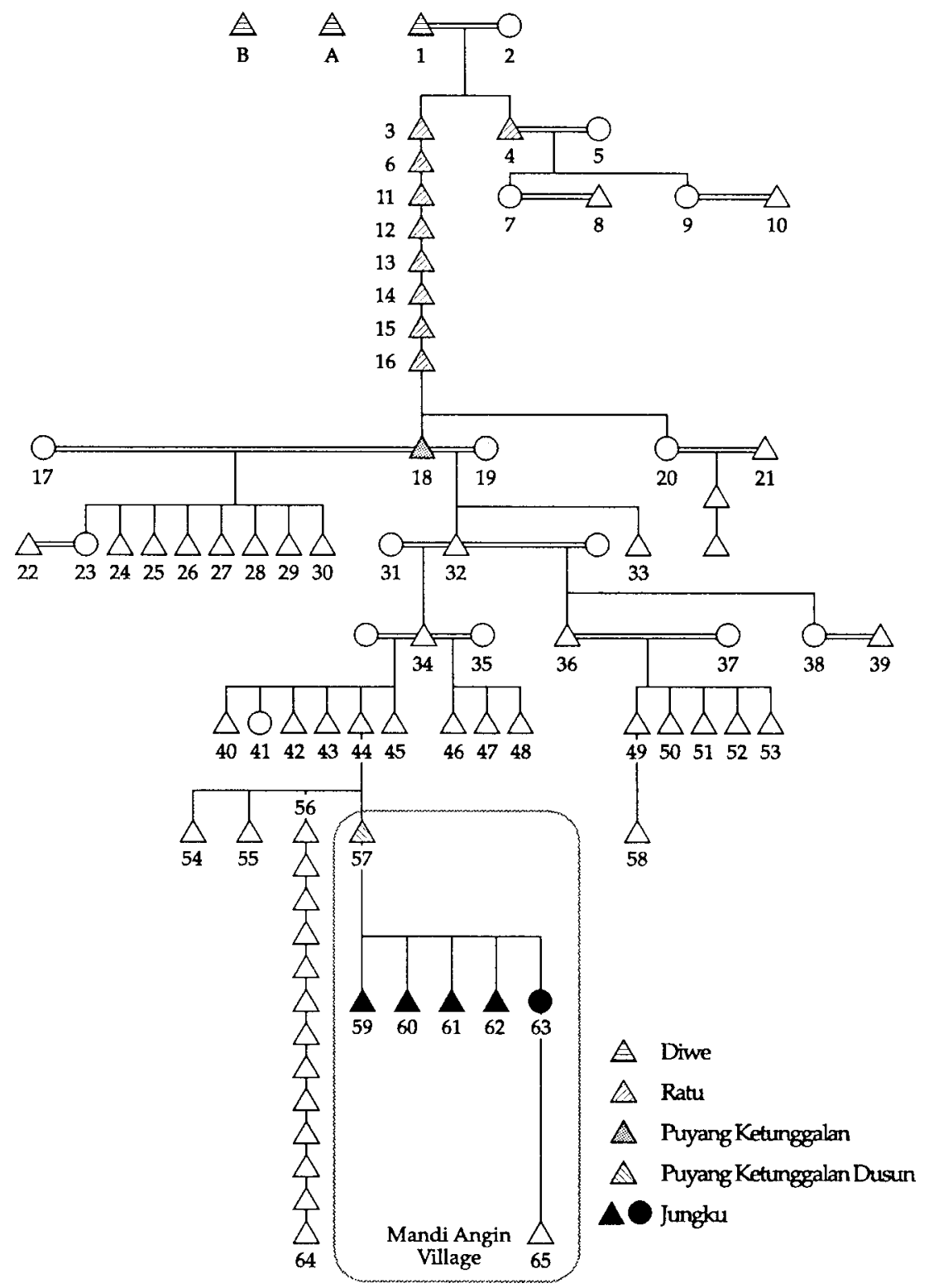

Figure 1. Genealogies of Jurai Kebali'an and of Mandi Angin village

Diwe Gumai possessed the title Jurai Kebali'an which has been passed on to descending male generations. The Jurai Kebali'an is the ritual specialist who acts to represent the whole Gumai offspring and to communicate with their ancestors. Before the demise of Diwe Gumai, his son, Ratu Iskandar Alam, became the second Jurai Kebali'an. Diwe Gumai left him all his heirlooms, which included a spell to call upon him in the sky. This spell, uttered every time the Jurai 
Kebali'an performs origin rituals, must not be made known to anyone except the Jurai Kebali'an.

Now let me explain the features of Ratu. The second Jurai Kebali'an remained at Bukit Seguntang, and in due course his place was taken by his son, Ratu Jemenang Sakti. Figure 1 shows the lineal succession of male descendants from the third to the ninth Jurai Kebali'an and that all their names include the title Ratu (see 6, 11, 12, 13, 14, 15, 16, Figure 1). The last Ratu (16) set up the first village in Kute Bantare in Rambang, where the Gumai started cultivating dry rice and hunting. He had a son and a daughter, Puyang Raden Simbang Gumai (18) and Putri Renik Dabung (20). ${ }^{24}$ Putri Renik Dabung married Junjungan di Laut, Ratu Siak Nage, who was half a crocodile (21). ${ }^{25}$

The title held by Puyang Raden Simbang Gumai (18), Puyang Ketunggalan, represents another crucial Gumai origin point to be remembered. He was the first ancestor referred to as puyang. This title emphasizes his special position in Gumai genealogy. He was the first to have ten children - nine sons and one daughter (23-30, 32-33). They went to new lands to set up new villages, which eventually led to the spread of Gumai descendants over South Sumatra. The Gumai state that each son followed one of the Nine Big Rivers that flow across South Sumatra to establish a new village. ${ }^{26}$ Today all the Gumai descendants claim that they originate from an ancestor who can trace his/her origin to one of the children of Puyang Raden Simbang Gumai.

The next important origin point for the Gumai to know about is Puyang Ketunggalan Dusun. Each apical ancestor of the Gumai who established a new village is called Puyang Ketunggalan Dusun (the Single Village Ancestor) or Petunggu Dusun (Guardian of the Village) and is buried in the graveyard within the original village. ${ }^{27}$ In the case of Mandi Angin village of Gumai Talang, Puyang Ketunggalan Dusun is represented by no. 57. These Gumai village founders have putative genealogical relations with the Jurai Kebali'an. Gumai villages still today consist of people who are affinally or lineally related to this founding ancestor. For the majority of the Gumai, the Puyang Ketunggalan Dusun constitutes their origin point at their village level.

Jungku or sungut is an origin point of a subgroup within a village. In the case of Mandi Angin village, they are represented by nos 59-63. It is through a jungku that the title of Jurai Tue, the caretaker of Gumai adat or custom, is transmitted. This position has been inherited from the first jungku founder, who was the child of the founding ancestor and was trusted to act as the caretaker of the village. ${ }^{28}$ A Gumai village consists of several jungku, one of which is responsible for choosing someone for the role of the Jurai Tue (65). The persons chosen are requested to live on their ancestral land and to have offspring. 
The authority and the realm of the Jurai Tue derive from his genealogical connections to the Puyang Ketunggalan and his association with the ancestral village. The authority to act as the Jurai Tue is limited to his village; he cannot act as the Jurai Tue for other Gumai villages. ${ }^{29}$

The lowest Gumai origin point is Puyang Keluarge (Family Ancestors). The Gumai refer to ascending generations above great-grandparents as puyang. These generations are called puyang even when they are still alive. Puyang Keluarge generally refers to ancestral spirits traced from their residential village and going back approximately four generations.

The process of generation of Gumai origin points highlights the nature of ritual specialists who perform corresponding origin rituals. It has also articulated features of Diwe, Ratu, Puyang Ketunggalan and Puyang Keluarge and the hierarchy of ancestral spirits. During the period from the Diwe to the Ratu, the principle was sequential lineal succession of the Jurai Kebali'an. All the Ratu are believed to have returned to the negeri atas angin at the time of their death. All of the Ratu daughters denote the supernatural as they married guardians of the spheres of the world. Puyang is an ancestor associated with a particular origin place (village). In the next section, I will present general features of interaction between ancestors and their descendants in order to investigate the affiliations between ancestral spirits and places.

\section{Genealogical Idioms by Which Relationships to Places are Expressed}

The Gumai believe that ancestors will assist in fulfilling the wishes made by their descendants. Wishes can be made at any place, but it is not uncommon for the Gumai to make a vow at the grave. Visits to tombs are called beziarah or the Gumai simply say "we will go to ancestors" (kami nak ke puyang). By burning incense made from benzoin (menyan) at a tomb, they speak to their ancestor/s to report on the expansion of the family. New members (mostly in-laws and new babies) are usually introduced to the ancestors. If they are in difficulties, this visit (ziarah) provides an opportunity to ask for the ancestor's help. They say, "if you help me and my wish comes true, I will come again, bring my family, slaughter a goat here and hold a big gathering" (sedekah). This is called making a vow or pledge (memasang niat). They promise that they will present sacrificial animals if their ancestors assist in fulfilling their wishes. Goats, chickens and water buffaloes are frequently slaughtered. ${ }^{30}$ Fulfilling a promise to their ancestors is called mbayar nazar, or mbayar sangi (paying off a promise).

Forgetting one's "origin" is believed to bring about all kinds of misfortune. When the Gumai have a traffic accident, suffer from any kind of disease, fire or death, they will search for a cause, and it is often ascribed to the family who did not "remember their origin". This is referred to as keselunagan, kesalahan or 
kuwalatan, which means punishment by ancestors for misbehaviour towards them. Even unfulfilled promises made by a deceased member of the family can cause misfortune to their descendants, such as a succession of accidents, sickness and infertility. Thus the Gumai believe that benevolent ancestors will become malevolent if not remembered properly.

The Gumai concerns with origins are also represented by places associated with their ancestors. it is a Gumai obligation (wajib) to remember his/her origin. Remembering origin (ngingat asal) is not just keeping a record of one's genealogy. One must also take certain actions such as visiting one's origin place and holding a gathering there. The gathering, sedekah, is performed at the house of relatives who occupy the place of their forebears and who receive their relatives when they return to their origin place.

Therefore an ancestral place, especially an ancestral village, holds significant value for the Gumai. The right to live in a village derives from Gumai genealogical affiliation with the ancestral village. It is prohibited to live in a village where one can trace no relations either lineally or affinally. ${ }^{31}$ Because of this exclusive residential rule, it is not uncommon to relocate a village site so that all the villagers can move to a new village for easier access to the main road. In order to maintain their affiliation with the ancestral place, the Jurai Tue brings a handful of soil and the trunk of an areca nut tree (pinang), both of which are planted in the centre of the new village.

The Gumai express a strong affiliation with their place of birth and residence as their "origin place". The village where a person was born and raised is considered to be his/her origin place (asal). ${ }^{32}$ Affiliation with asal also plays an important role at the time of death. The Gumai all expect to be buried in their ancestral graveyard. Despite Islamic teaching and the costs of transferring a dead body, it is not unusual to transfer the body of someone who has died in Jakarta all the way back to their own village for burial. Even after many years of outmigration to other towns, the Gumai consider that the bodies should be returned to their ancestral villages. ${ }^{33}$

The next section elaborates on how this affiliation between ancestors and places underpins each of the Gumai origin rituals practised at various origin points.

\section{Origin Rituals, Ritual Specialists and Ritual Places}

The Gumai do not have social strata. The only demarcation made is by succession to the roles of ritual specialists for Gumai custom and tradition, the Jurai Kebali'an and the Jurai Tue. ${ }^{34}$ Gumai ritual specialists do not traditionally have inherent secular power. 


\section{Origin Rituals, Ritual Specialists and Ritual Places}

The Gumai origin ritual for the whole society is called Sedekah Malam Empatbelas. It takes place every month on the thirteenth night according to the lunar calendar, which is when the Gumai believe Diwe Gumai descended to earth. It is held at the house of the Jurai Kebali'an (64), who is the twenty-sixth successor from Diwe Gumai and resides in Endikat Ilir village of Gumai Talang. The participants in this ritual are Gumai descendants in the southern part of Sumatra. Participants come to this ritual in order to make wishes, to pay off their promises and to ask for medicine, such as ointment. The ritual starts in the morning with the slaughter of participants' sacrificial animals for repaying promises, followed by the cooking of dishes and the organization of elaborate offerings. ${ }^{35}$ It proceeds to rituals involving invocations of ancestors at night. ${ }^{36}$ During my fieldwork period, Sedekah Malam Empatbelas consistently attracted about 250 people each month. ${ }^{37}$

Sedekah Malam Empatbelas consists of two parts, Sedekah Khusus and Sedekah Umum, both of which centre around invocations of ancestral spirits by the Jurai Kebali'an. The Sedekah Khusus is a ritual in which the ancestral spirits of Jurai Kebali'an's direct line are invoked. By burning incense and uttering spells, the Jurai Kebali'an starts invoking the spirits of his deceased father and proceeds up to Diwe Gumai to ask for the welfare of the Gumai descendants.

The Sedekah Umum is a ritual in which all the ancestral spirits of the participants are invoked. The Jurai Kebali'an reports the wishes made by participants and the fulfilment of promises to Gumai ancestral spirits. The highest spirit invoked in this ritual is Puyang Ketunggalan (18) since he is the unitary point and source of the expansion of all the Gumai descendants.

The Jurai Kebali'an is the ritual specialist for the whole Gumai community. ${ }^{38}$ In addition to performing the Sedekah Malam Empatbelas, he performs rituals at the time of crisis and calamity. ${ }^{39}$ The position of the Jurai Kebali'an is reckoned though this male line. Neither birth order nor seniority determines who will inherit the position. ${ }^{40}$ Personality and responsibility qualify a person to be successor. ${ }^{41}$

The words Jurai Kebali'an consists of two parts. Jurai is Gumai word for descendants. Kebali'an, derived from bali', means to return. Thus, the connotation is that the title signifies the place to which all the Gumai descendants should return. In line with this underlying meaning, the Jurai Kebali'an's house is open to all Gumai descendants. It is regarded as the origin house for all Gumai. It not only accommodates the Jurai Kebali'an's own family members, but also all other Gumai descendants. Every day someone comes to his house for consultation, and no less than ten people may be staying there. ${ }^{42}$ 
The Jurai Kebali'an's source of authority and his prerogatives over Gumai adat derive not only from his position as an heir, but also from his location at the origin house. As long as he is within the house of the Jurai Kebali'an, he can function as the Jurai Kebali'an. The Gumai say that "the Jurai Kebali'an does not go anywhere, he always stays home" (Jurai Kebali'an dide pegi ke mane mane, tetap di humah). This "house" (humah) consists of a house and a garden. When the Jurai Kebali'an is away from this compound, for instance at his second wife's house, he becomes a regular individual and is not able to play a role as the Jurai Kebali'an, His second wife's house is not regarded as the origin house for the Gumai. Thus, it is not appropriate for him to deal with Gumai adat issues when out of the Jurai Kebali'an's house. The Jurai Tue reporting to the Jurai Kebali'an about adat issues should go to the Jurai Kebali'an's house. If he is absent, it is legitimate to report to Jurai Kebali'an's wife or her children.

Inside his house, access to Jurai Kebali'an's bedroom is strictly restricted at all times; even his wives cannot sleep there. This is because the Jurai Kebali'an invokes his ancestral spirits at the time of Sedekah Malam Empatbelas inside this bedroom. Heirlooms are kept on a high platform in this room. It is therefore regarded as the special place for the Jurai Kebali'an to undertake the Sedekah Malam Empatbelas and to sleep in. ${ }^{43}$ Sedekah Malam Empatbelas cannot be performed at any other place but the house of the Jurai Kebali'an.

His genealogy as the Jurai Kebali'an, which directly serves to connect his origin with the founding ancestors, his knowledge about spells to invoke ancestral spirits at Sedekah Malam Empatbelas and his location at the origin house, constitute the authenticity of the Jurai Kebali'an. It is significant that the Jurai Kebali'an's ancestral spirits must be invoked at the house of the Jurai Kebali'an and be performed by himself. Thus, this invocation does not represent a mere genealogy, but also a succession of ancestral names attached to this Gumai origin place.

\section{Origin Rituals and the Ritual Specialist for a Village}

The origin ritual for a village is called Sedekah Pedusun, Sedekah Peliare Dusun or Sedekah Petunggu Dusun. It is meant for the village guardians and Puyang Ketunggalan Dusun, and traditionally took place in relation to Gumai agriculture. The first sedekah took place prior to clearing a piece of land, the second three months after rice planting and the third after the harvest of new rice. At present, the ritual is held once or twice a year in the house of the Jurai Tue. ${ }^{44}$ The rituals are attended by male members within the village who are household heads. A set of offerings is prepared by the wife of the Jurai Tue. The core of this ritual comprises an invocation of the Jurai Tue's "genealogy" in order to ask for the well-being of the villagers, including a good harvest. The Jurai Tue recites a succession of ancestral names starting from his deceased parents upward to the 
village founder. By doing so, all the spirits of forebears derived from the village founder can be called upon. After their invocation, the participants enjoy a feast.

The duty of the Jurai Tue is to act as the caretaker of Gumai adat. ${ }^{45}$ The title of the Jurai Tue can be transmitted to either a male or a female, but the role has to be enacted by a male member. If a woman is appointed to the office, her husband is supposed to carry out the duties as the Jurai Tue in that village. The genealogical affiliation of this husband with the founding ancestor does not create a problem. As long as he is married to the woman with the title of Jurai Tue and lives with her, he is expected to function as the Jurai Tue. If she dies or divorces him, he is no longer able to carry out duties of Jurai Tue. In general, the Jurai Tue is expected to have a spouse, and a widowed person, male or female, is not eligible. In practical terms, the wife of the Jurai Tue has to prepare offerings every time there is a sedekah, while he slaughters sacrificial animals and performs the core of the sedekah by invoking the ancestral spirits.

What is special about the Jurai Tue is the depth of their knowledge about their genealogies. While non-ritual specialists' knowledge of genealogies does not exceed four generations, it is the responsibility of the Jurai Tue to trace his genealogy to the founding village ancestors, the origin-point in the village (Puyang Ketunggalan Dusun). The genealogy of this village origin point has putative genealogical connections with the Jurai Kebali'an.

As is evident from the way in which succession to the title of the Jurai Tue takes place, the genealogies of the Jurai Tue are neither patrilineal nor matrilineal: they are a succession of ancestral names traced through residential locality. The spirits of ancestors who had married a person with the title of Jurai Tue are also invoked in origin rituals practised by the Jurai Tue. The underlying logic is the genealogical connection which is associated with his/her origin place. This way of tracing social origin is also practised by the Gumai when they cite male and female names in a succession when talking about their pedigree.

Origin rituals of a family need to take place at the family's origin place. In order to maintain affiliation with the ancestral village, one child is always encouraged to stay at his or her parent's place. This rule is called nuduko'ka jurai, or menunggu dusun. He or she, once officially announced, normally inherits the house of origin and agricultural fields, and is obliged to produce offspring in the natal place. This is called tunggu tubang. There is no special preference for men or women for tunggu tubang among the Gumai. His/her house should accommodate relatives when they wish to return to their birth place and is used for the venue of a sedekah. The house and the owner of the house are regarded as the representation of the ancestors in their village. The heir cannot make the decision to sell this house by him/herself. The decision should be made through discussion with his/her siblings. In principle, the house cannot be sold to anyone who does not have traceable genealogical connections with the village. 
The Gumai are encouraged to return to their origin place once in a while to perform a sedekah. If this presents the individual/s involved with problems due to the expense of the ritual, the Gumai are encouraged to perform tandang sedekah. Tandang means to sleep in someone's house, but in this context it means to hold a sedekah at someone's house. When those who have not been to their ancestral village for a long time eventually return to their village to attend a sedekah (such as marriage ceremony or circumcision) organized by someone else, they often contribute sacrificial animals to the family holding the sedekah in order to prove their connections with this village. Their intention is to show that they have not forgotten their ancestral village and their contribution of sacrificial animals is proudly announced in public at the sedekah.

To end this section, I will present a case which will exemplify Gumai concerns with origins which are represented by persons and places. In this case, a family who had lost contact with their origin created a new "authentic" origin place and performed a sedekah.

\section{Case}

Dewi (a pseudonym), a woman from Lintang, was married to Arpan (a pseudonym), and lived in a village in the subdistrict of Ulu Musi in the Lahat district. Dewi's husband's great-grandfather was said to be from Gumai Talang, but Arpan himself had never been to his great-grandfather's village, nor did he know exactly to which village his great-grandfather belonged. Dewi's sudden sickness began after they had lost three grandchildren. One day she felt as if someone was stabbing her lower back with a knife. Dewi's husband called a local healer (dukun) and he pointed out that Ade kesalahan di sebelah laki ("There has been a wrong to ancestors on the husband's side"). Dewi became unconscious and possessed, and said, "Yes, I admit that our family originated from Gumai. If I become healthy again, I will bring a goat there. The medicine will be available one kilometre away from this home". The family searched and came to a hut in the field (pondok). They found a piece of benzoin. ${ }^{46}$ So they burnt it to confirm their promise that they would visit the origin village of their great-grandfather.

However, they did not know any relatives who could be genealogically traced in Gumai Talang. They only knew Mim, a son of Soleh who lived in Muara Tandi of Gumai Talang, because Mim was the best friend of Yaman, a grandchild of Arpan's brother. The friendship between Mim and Yaman was so intense that they even developed adopted "brother" relations. ${ }^{47}$ Therefore, it was decided that the sedekah would take place at Soleh/Mim's house. The family of Arpan chartered a mini-bus and travelled with sacrificial animals over $130 \mathrm{~km}$ in order to undertake a sedekah in their ancestral land. 
This case demonstrates that the venue of the sedekah for origin rituals can be created through "adopted" genealogical ties to ancestral land. The affiliation through personal ties and ancestral land is crucial for the Gumai origin concerns.

\section{Conclusion}

The Gumai way of tracing their social origin is represented by a succession of ancestral names connected to the origin places. These places form a hierarchy of Gumai origin points which are connected with origin rituals by specialists for each origin point.

Several origin cults are performed because the Gumai recognize various origin points, each represented by ancestors affiliated with specific places. Each of these origin points has to be remembered by the respective ritual and ritualist. What is central to the Gumai are the associations of "person" and "place" which underpin the Gumai concerns with origins. To maintain associations, rituals depending on origin points are undertaken at the corresponding origin place.

Failure to maintain ties is believed to infuriate the ancestral spirits and will cause misfortune among their descendants.

The authority of the Gumai origin ritual specialists derives from their genealogies traced through an origin point. It is therefore their genealogical connections with their ancestors and their association with origin places that enable Gumai ritual specialists to perform origin rituals and to convey the wishes of Gumai descendants on their behalf. Remembering "origin" means to return to an origin point, both genealogical and spatial.

\section{References}

Andaya, Barbara Watson

1989 The cloth trade in Jambi and Palembang society during the seventeenth and eighteenth centuries. Indonesia 48:27-47.

1993 To live as brothers: southeast Sumatra in the seventeenth and eighteenth centuries. Honolulu: University of Hawaii Press.

Brown, C.C.

1970 Sejarah Melayu or Malay annals. An annotated translation by C.C. Brown, with a new introduction by R. Roolvink. Kuala Lumpur: Oxford University Press.

Collins, William

1979 Besemah concepts: a study of the culture of a people of South Sumatra. PhD thesis, University of California, Berkeley.

Connor, Linda, Patsy Asch and Timothy Asch 
1986 Jero Tapakan, Balinese healer: an ethnographic film monograph. Cambridge and New York: Cambridge University Press.

de Josselin de Jong, P.E.

1964 The character of the Malay Annals. In J. Bastin and R. Roolvink (eds) Malayan and Indonesian studies: essays presented to Sir Richard Winstedt on his eighty-fifth birthday, pp.235-241. Oxford: Clarendon Press.

Drakard, Jane

1990 A Malay frontier: unity and duality in a Sumatran kingdom. Ithaca: Southeast Asia Program, Cornell University Press.

Dobbin, Christine

1975 The exercise of authority in Minangkabau in the late eighteenth century. In A. Reid and L. Castles (eds) Pre-colonial state systems in Southeast Asia: the Malay Peninsula, Sumatra, Bali-Lombok, South Celebes. Monographs of the Malaysian Branch of the Royal Asiatic Society No. 6. Kuala Lumpur: The Malaysian Branch of The Royal Asiatic Society.

Foley, W.A.

1981 Sumatra. In S.A. Wurm and Shiro Hattori (eds) Language atlas of the Pacific area. Canberra: The Australian Academy of the Humanities in collaboration with the Japan Academy.

Fox, J.J.

1995 Origin structures and systems of precedence in the comparative study of Austronesian societies. In Paul Li, Cheng-hwa Tsang, Ying-kuei Huang, Dah-an Ho and Chiu-yu Tseng (eds) Austronesian studies relating to Taiwan, Symposium series of the Institute of History and Philology, Academia Sinica, 3, pp.27-57. Taipei, Taiwan, ROC: Academia Sinica.

1996 Introduction. In J.J. Fox and C. Sather (eds) Origin, ancestry, and alliance: explorations in Austronesian ethnography, pp.1-17. Canberra: Department of Anthropology, Research School of Pacific and Asian Studies, The Australian National University.

Fox, J.J. (ed.)

1993 Inside Austronesian houses: perspectives on domestic designs for living. Canberra: Department of Anthropology, Research School of Pacific Studies, The Australian National University.

Galizia, M.

1995 Aufstieg und Fall der Pasirah: Zentralstaatliche Vereinnahmung und lokale Machtstrategien. Berlin: Reimer. 
1996 Village institutions after the Law no. 5/1979 on village administration. The Case of Rejang-Lebong in South-Western Sumatra. Archipel 51:135160 .

Hollan, Douglas

1989 The personal use of dream belief in the Traja Highlands. Ethnos 17(2):166186.

Hirosue, Masashi

1993 Port of trade polities and hinterlands in North Sumatra. Southeast Asia: History and Culture 22:3-35.

Jensen, Erik

1974 The Iban and their religion. Oxford: Clarendon Press.

Kathirithamby-Wells, J.

1993 Hulu-hilir unity and conflict: Malay statecraft in East Sumatra before the mid-nineteenth century. Archipel 45:77-96.

Lipinsky, E. and T. Kato

n.d. Land tenure and village administration: Sumatra regional planning study, Province [of] South Sumatra. Bonn: University of Bonn.

Mabuchi, Toichi

1974 Magico-religious land ownership in general Formosa and Southeast Asia. In Ethnology of the Southwestern Pacific: the Ryukyus-Taiwan Insular Southeast Asia. Taipei: The Chinese Association for Folklore.

Mitani, Yasuyuki

1980 Languages of South Sumatra. In Y. Tsubouchi, N. Iljas, Y. Takaya and A.R. Hanafiah (eds) South Sumatra man and agriculture. Kyoto: Center for Southeast Asian Studies, Kyoto University.

Moyer, David

1984 South Sumatra in the Indonesian field of anthropological study. In P.E. de Josselin de Jong (ed.) Unity in diversity: Indonesia as a field of anthropological study. Dordrecht-Holland/Providence: Foris Publications.

Rustam-Effendi

1993 Gumai perang melawan belanda. Lahat: Sumber Karya.

Steadly, Mary Margaret

1993 Hanging without a rope: narrative experience in colonial and postcolonial Karoland. Princeton: Princeton University Press.

Suzuki, Tsuneyuki 
1996 Palembang okokuni okeru nairiku shihai sedo. Tokyo Joshi Daigaku Shiron 49:1-21.

Teeuw, A.

1964 Hikayat raja-raja pasai and Sejarah Selayu. In J. Bastin and R. Roolvink (eds) Malayan and Indonesian studies: essays presented to Sir Richard Winstedt on his eighty-fifth birthday. Oxford: Clarendon Press.

\section{Tomizawa, Hisao}

1981 A structural analysis of the Sejarah Melayu: an essay on a Malay dynastic myth. Minzokugaku-Kenykyu: the Japanese Journal of Ethnology 46(1): 55-79.

\section{Voorhoeve, Petrus}

1955 Critical survey of studies on the languages of Sumatra. 's-Gravenhage: M. Nijhoff.

Waterson, Roxana

1990 The living house: an anthropology of architecture in South-East Asia. Oxford: Oxford University Press.

Weinstock, Joseph A.

1987 Kaharingan in southern Borneo. In R.S. Kipp and S. Rodgers (eds) Indonesian religions in transition. Tucson: The University of Arizona Press.

\section{Notes}

1 I wish to thank Professors Barbara Andaya, James J. Fox and Amran Halim; Drs Barbara Holloway, Ian Proudfoot and Kathy Robinson. I also wish to thank Professor Anthony Reid and Dr Amanda Scott for their reading of, and comments on, earlier versions of the draft. Discussions with Professor Fox have provided me with invaluable insights. I am deeply grateful to the Gumai in South Sumatra, especially the family of Bapak Rumsyah, the present Jurai Kebali'an, who kindly accepted and supported my research.

2 A problem arising from the notion of "descent" for comparative studies on Austronesian speakers has been raised. One of the key issues this paper reflects is explained in Fox (1995:33-34),

it is purportedly a matter of significance that many Austronesian societies have no "descent groups" and indeed, the very notion of "descent" appears somewhat questionable in regard to such societies. ...The use of the notion of descent may thus inhibit, rather than foster, efforts at comparison.

Whereas a concern with "descent" may be of variable interest or of complete indifference in Austronesian societies, a concern with "origins", variously defined, is a matter of the greatest concern.

${ }^{3}$ Place and place names constitute an important dimension of Austronesian origin concern. Fox (1996:5) states "recourse to notions of place is also critical in identifying persons and groups, and thus tracing origins". Many Austronesians identify houses specifically as their origin sites. For discussions of houses and origin sites, see Waterson (1990) and Fox (1993 and this volume).

4 My fieldwork on the Gumai in South Sumatra was undertaken over twenty months from May 1994 to March 1996. The research was undertaken under the auspices of LIPI, the Indonesian Institute of Sciences, and sponsored by Universitas Sriwijaya in Palembang. At various stages of this research, it was financially supported by research grants from the Daiwa Bank Foundation for Asia and Oceania and the Matsushita International Foundation, and a PhD scholarship from The Australian National University. I am grateful for their generous support. 
${ }^{5}$ Numerous local dialects, traditionally known as Middle Malay (Voorhoeve 1955) are spoken in various districts in the highlands. They are spoken by neighbouring ethnic groups such as Lematang, Rambang, Belida, Besemah, Semendo and Serawai. Professor Amran Halim states that there are four Malay variants recognizable in South Sumatra Province (personal communication). They are the $o, e$, stressed é, and au variants. The vowel at the end changes as follows: "mana" (where) in Bahasa Indonesia is realized as "mano", "mane", "mané" and "manau" respectively. Mitani (1980) states that local differences between the Malay dialects of South Sumatra are not great enough for further classifications yet he draws attention to a difference between Musi Malay and Highland Malay. For a map of Malay language distribution, details of Malay language in Sumatra, see Foley (1981) and Mitani (1980). The diversity and spread of variants of Malay dialects coincide with the geographical spread of the Gumai in Southern Sumatra. However, since as yet no full studies of Southern Sumatran dialects have been undertaken, the connection between Malay variants and Gumai territorial expansion processes cannot be tested. As the Besemah, a neighbouring ethnic group with different founding ancestors, outnumber the Gumai, the Gumai language is often called Bahasa Besemah by outsiders such as people in Palembang. The Gumai themselves refer to their language as Bahasa kite (our language) or Bahasa dusun (village language).

6 Two other Gumai settlements are Gumai Ulu and Gumai Lembak in Pulau Pinang subdistrict of Lahat District.

${ }^{7}$ Due to this easy access to transportation, the Gumai Talang villagers travel to Lahat, the district capital or even to Palembang, the capital city of South Sumatra Province, approximately $220 \mathrm{~km}$ away, for shopping and education.

8 For detailed historical studies of trade and upland and lowland relations in southeast Sumatra, see Andaya $(1989,1993)$. Trade also connected the interior peoples of northern and eastern parts of Sumatra to coastal port polities. For studies in North Sumatra, see Drakard (1990) and Hirosue (1993) and for an overview of East Sumatran cases, see Kathirithamby-Wells (1993).

9 Suzuki (1996:1-21) classifies this area under the rule of the Sultanate of Palembang into three administrative regions according to the nature of their obligations to the Sultanate as subjects. The Gumai area near Lahat belongs to Sindang, in which the border control and tribute were major obligations. 10 Lipinsky and Kato (n.d.) state that the pasirah system was originally a development in conjunction with the Palembang Sultanate. The pasirah was titled Depati. For a case study of a pasirah system in southwest Sumatra, see Galizia (1995).

11 This change derives from Undang-Undang Republik Indonesia No.5 Tahun 1979 tentang Pemerintahan Desa. For a study on the effect of implementation of this law in southwest Sumatra, see Galizia (1996).

12 The belief that the spirits are the primary owners of the land is widely shared among Austronesian speakers as well as non-Austronesians. For an Austronesian example, see Mabuchi (1974).

13 The sickness cannot be cured without carrying out a curing ritual called beruroh.

14 The same logic works prior to clearing a field or constructing the main pillars of a house.

15 Arwah is a Gumai term for soul/s of the deceased, which differ from guardian spirits of the spheres of the world. Puyang (ancestors) can be used to refer to generations above grandparents.

16 The Sejarah Melayu, commonly translated as the Malay Annals, is not a chronicle but "a story setting out the descent of Malay Rajas with their customary ceremonial" (Brown 1970:x). It recounts the descent of the first Malay kings who claimed to be offspring of Alexander the Great. For the nature of various Malay origin stories, see de Josselin de Jong (1964) and Teeuw (1964). Based on a structural analysis of the Malay origin stories, Tomizawa (1981:67-68) states that the integration of the three spheres (sky, earth and water) constitutes an important theme in Malay cosmology. The following Gumai origin myth cited in this paper illustrates this integration process.

17 This timing is still used for performing rituals called Sedekah Malam Empatbelas in which all the ancestral spirits are invoked by the Jurai Kebali'an.

18 Bukit Seguntang is a hill in Palembang which is believed to be the place where the first three kings descended from heaven according to the Sejarah Melayu (Brown 1970: 14). These three princes claimed to be descendants of Raja Iskandar Dzu'l Karnain (Alexander the Great) and they were met by two women there. Currently there exist several graves on Bukit Seguntang, the identities of which are not determined. Gumai informants told me during my fieldwork that several graves existed and two of them are believed by the Gumai to be the graves of the wife of Diwe Gumai and her son, Ratu Iskandar Alam. These graves are sometimes visited by the Gumai.

19 Bracketed single numbers and letters correspond to symbols in Figure 1.

20 To remember this incident, the Jurai Kebali'an is prohibited from eating this fruit, kundur. Based on their origin account, a Gumai ritual specialist, Jurai Tue, explained to me that the word Gumai may be 
divided into two parts, the first gum means "descended first", and mai means "just became visible, and real". In daily life these words are not in use. Collins (1979:24) collected this origin myth from a Besemah informant and mentioned that Diwe Gumai and Diwe Semidang disputed over who was actually the elder, but the Gumai ritual specialists I spoke to just emphasized that Diwe Gumai descended first and did not mention the dispute between Diwe Gumai and Diwe Semidang.

21 Atong Bungsu (B), another founding ancestor of the Besemah, descended on Bukit Seguntang after the world had become populated.

22 The Gumai claim that Gumai communities exist in Pagarruyung. Pagarruyung constitutes the heartland of the Minangkabau and the seat of the Raja Alam, who claimed to be a descendant of Alexander the Great, and one of the three Supra village Minangkabau chiefs was located there. For details, see Dobbin (1975).

23 The spirit of Putri Kumbang Mibar is considered to reside in Mt Dempo near Pagaralam. The spirit of Putri Kumbang Nadar is considered to live in the sky.

24 Puyang Raden Simbang Gumai is widely known as Puyang Suke Milung.

25 Putri Renik Dabung was kidnapped by Ratu Siak Nage and her brother, Raden Simbang Gumai, went underwater to look for his lost sister.

26 Batang Hari Semblian (Nine Big Rivers) implies the whole area of South Sumatra, since numerous rivers flow across the southern part of Sumatra.

27 Due to several village relocations, many Gumai villages do not have the tomb of this founding ancestor within the present village site. Some villages have a monument (tapak) to represent the founding ancestor's grave.

28 It should be noted that the jungku member who carries out the role of the Jurai Tue is not always the eldest child. The eldest jungku member is respected and is called tue jurai, which means "the eldest offspring".

29 Some Jurai Tue in Gumai Talang no longer reside in their own villages. One Jurai Tue resides in his wife's village within Gumai Talang, but he cannot act as the Jurai Tue for this village. He returns to his village where he is supposed to act as the Jurai Tue in order to perform origin rituals.

30 The colours of sacrificial animals, in particular those of chickens and goats, are crucial for performing their rituals. Choosing wrong-coloured animals makes the ritual invalid.

31 Previously, there were two types of marriage which prescribed residential patterns. Belaki was a marriage of patrilocal residency. Tambi anak berape duit was a marriage of uxorilocal residency. In both types, when the person who originally belonged to the village died, the classificatory sister/brother was supposed to re-marry the widowed partner to continue the marriage (nungkat). For a historical study of connubium principles in South Sumatra, see Moyer (1984).

32 In the case of a child's parents taking virilocal residence, a Gumai would tend to emphasize more affiliation with forebears among paternal kin. In cases of uxorilocality, a child would tend to find more affiliation with the mother's village of origin. If asked where he/she is from, the reply is determined by the place or village where he or she has spent most of his/her life.

33 The Gumai in towns, out of their origin villages, tend to have Gumai as a part of their name. In Gumai Talang, people do not include Gumai in their name.

34 I have not discussed the Mimbar in this essay. At present the Mimbar are not as significant or active as the Jurai Tue and the Jurai Kebali'an.

35 During my fieldwork, the average number of goats used for a sacrificial purpose each month was sixteen.

36 The first wife of the Jurai Kebali'an is responsible for receiving guests and arranging offerings. Guests also actively participate in cooking, dish washing and cleaning the house.

37 Since the majority of them are peasants, they have more free time after the rice harvest in the dry season (June, July). This timing coincides with school holidays in Indonesia, and during these two months, the number of participants reached about six to seven hundred (including children).

38 The term balian in Indonesia is frequently used to refer to a shaman/spirit medium. For an example from Bali see Connor, Asch and Asch (1986) and for an example from Kalimantan see Weinstock (1987). Yet Jurai Kebali'an is not a shaman who can be possessed by ancestral spirits, rather he is a priest who can mediate between ancestral spirits and their descendants.

39 The Jurai Kebali'an performs Sedekah Nimbang Beneh (the ritual of weighing of rice seeds), which is practised only when the Gumai have a succession of bad crops. A better crop is asked for through an 


\section{The Poetic Power of Place}

invocation of Gumai ancestral spirits by the Jurai Kebali'an. Sedekah Upat Diwe is a cleansing ritual for the family of the Jurai Kebali'an.

40 In the case of polygamy, the heir is chosen from sons born to the Jurai Kebali'an's first wife.

41 The person who is suitable to act as the Jurai Kebali'an should have an ability to talk to anyone and to think on behalf of others. He should not easily lose his temper. Being thoughtful and active in the community constitutes a key element.

42 People who are suffering from financial problems, and/or who cannot stay in their village for various reasons always stay at the Jurai Kebali'an's house. They help to clean the house, take care of the gardens, and receive free food during their stay. They say that the house of the Jurai Kebali'an is their origin house, and they believe that it is their own house. The Jurai Kebali'an's family cannot prevent anyone coming to stay, as they admit that guests also belong to this house.

43 Among the Gumai, dreaming of ancestors is interpreted as a message from their ancestors. Dreaming in various Malay-Indonesian contexts provides a way to receive ancestral messages and to encounter spirits. See Hollan (1989) for a case on the Traja of Sulawesi, Jensen (1974:116-120) on the Iban of Sarawak and Steadly (1993:158-161) for the Karo Batak of North Sumatra.

44 At present, the timing is chosen to coincide with two major Islamic festivals, Idul Fitri and Idul Adhah because this is when all the villagers return to their own village from their gardens for prayers.

45 If there has been a breach of sexual conduct in his village, the Jurai Tue needs to perform a cleansing ritual (Sedekah Besehka Dusun) to cleanse the village and to apologize for this misbehaviour to the ancestors. Without such a ritual, the state of impurity is believed to cause calamity such as sickness and attacks by tigers. The Gumai abhor naming tigers (harimau). When they have to refer to tigers, they quietly say, "puyang", meaning ancestor. Crocodiles (buaye) are also regarded as Gumai ancestors, and the Gumai should not kill them.

46 In order to communicate with ancestral spirits, benzoin (menyan) is usually burnt in Gumai ancestral rituals.

47 It is not unusual for the Gumai to have adopted family relations, such as parent-child and/or sibling relations. Sometimes the Gumai hold a sedekah to announce in public the establishment of these adopted kinship ties. Those adopted have no right to claim property; however, they maintain close social ties with their family. 